\title{
High dietary intake of vitamin C suppresses age-related thymic atrophy and contributes to the maintenance of immune cells in vitamin C-deficient senescence marker protein-30 knockout mice
}

\author{
Ryusei Uchio $^{1 *}$, Yoshitaka Hirose ${ }^{1}$, Shinji Murosaki ${ }^{1}$, Yoshihiro Yamamoto ${ }^{1}$ and Akihito Ishigami $^{2}$ \\ ${ }^{1}$ Research and Development Institute, House Wellness Foods Corporation, 3-20 Imoji, Itami 664-0011, Japan \\ ${ }^{2}$ Molecular Regulation of Aging, Tokyo Metropolitan Institute of Gerontology, Tokyo 173-0015, Japan \\ (Submitted 23 July 2014 - Final revision received 20 October 2014 - Accepted 23 October 2014 - First published online 22 January 2015)
}

\section{Abstract}

Vitamin C (VC) is an essential nutrient for humans and certain other animals. It has antioxidant properties and has been reported to ameliorate oxidative damage to lipids, DNA and proteins. However, the effects of VC on immune function are poorly understood, especially the influence of long-term high-dose $\mathrm{VC}$ intake on the number and function of immune cells. In the present study, to evaluate the immune effects of VC, VC-deficient senescence marker protein-30 knockout (SMP30KO) mice were fed a diet containing the recommended level of $\mathrm{VC}(20 \mathrm{mg} / \mathrm{kg}$ per d; $0.02 \% \mathrm{VC})$ or a high level of VC $(200 \mathrm{mg} / \mathrm{kg}$ per d; $0 \cdot 2 \% \mathrm{VC})$ for 1 year. The plasma $\mathrm{VC}$ concentration of the $0.02 \%$ group was the same as that of age-matched C57BL $/ 6$ mice after 1 year of feeding; however, plasma VC concentration and thymus weight were significantly higher in the $0.2 \% \mathrm{VC}$ group than in the $0.02 \% \mathrm{VC}$ group. The total counts of leucocytes, lymphocytes, granulocytes and monocytes in the peripheral blood, as well as the number of splenocytes and thymocytes, were all significantly higher in the $0.2 \% \mathrm{VC}$ group than in the $0.02 \% \mathrm{VC}$ group. In addition, the number of naive T cells in peripheral blood lymphocytes, the number of memory T-cell populations in splenocytes, and the number of cluster of differentiation (CD) $4^{+} \mathrm{CD} 8^{+}$or $\mathrm{CD} 4^{+} \mathrm{CD} 8{ }^{-}$or $\mathrm{CD}^{-} \mathrm{CD}^{+} \mathrm{T}$ cells in thymocytes were all markedly higher in the $0 \cdot 2 \%$ VC group than in the $0.02 \%$ VC group after 1 year of dietary treatment. These results suggest that a long-term high-dose intake of VC is effective in the maintenance of immune cells, partly through the suppression of age-related thymic involution in VC-deficient SMP30KO mice.

\section{Key words: Vitamin C: Senescence marker protein-30 knockout mice: Thymus: Naive T cells}

Ageing is a complex process that affects a variety of physiological functions. It is widely accepted that the ageing process attenuates the immune response and results in greater susceptibility to infection or an increased risk of cancer ${ }^{(1)}$. The thymus is a central lymphoid organ responsible for the production of naive $\mathrm{T}$ cells, which migrate to the peripheral lymphoid tissues and play a vital role in mediating both cellular and humoral immunity. Age-related involution of the thymus is characterised by a decrease in its size, weight and cellularity, along with structural and functional impairment, culminating in a decrease of cells entering the peripheral T-cell pool. Chronic involution of the thymus is thought to be one of the major factors contributing to the decline of immune function with increasing age $\mathrm{e}^{(2,3)}$.

Vitamin C (VC) is an essential micronutrient that is required for normal metabolism in humans. It is essential for the biosynthesis of collagen and L-carnitine ${ }^{(4,5)}$, and is also known to be an antioxidant that protects against oxidative stress. The current RDA of $\mathrm{VC}$ is $75-90 \mathrm{mg} / \mathrm{d}$ in the USA or $100 \mathrm{mg} / \mathrm{d}$ in Germany, Switzerland, Austria and Japan ${ }^{(6)}$. Recently, dietary intake of $\mathrm{VC}$ at five to twenty times the RDA has been reported to decrease lipid peroxidation ${ }^{(7,8)}$, oxidative DNA damage in lymphocytes ${ }^{(9)}$, total cholesterol ${ }^{(10)}$, arterial stiffness $^{(11)}$ and endothelial damage ${ }^{(12)}$, as well as prevent the common cold ${ }^{(13)}$. It has also been reported that $\mathrm{VC}$ intake improves some immune cell functions ${ }^{(14-16)}$; however, the effects of long-term high-dose $\mathrm{VC}$ consumption on the number and function of immune cells are poorly understood.

Senescence marker protein-30 (SMP30) is a $34 \mathrm{kDa}$ protein that was originally identified in the rat liver, and its expression has been reported to decrease with age in both sexes ${ }^{(17)}$. SMP30 is also known as regucalcin (RGN) or gluconolactonase (GNL), and it acts as a lactone-hydrolysing enzyme in VC biosynthesis ${ }^{(18)}$. Recently, Ishigami et $a l^{(19)}$ established

\footnotetext{
Abbreviations: CD, cluster of differentiation; FBS, fetal bovine serum; FITC, fluorescein isothiocyanate; PE, phycoerythrin; PerCP, peridinin chlorophyll protein complex; SMP30, senescence marker protein-30; SMP30KO, senescence marker protein-30 knockout; SP, single positive; VC, vitamin C; WT, wild type.
} 
SMP30/GNL knockout (SMP30KO) mice and demonstrated that these mice display symptoms of scurvy such as fractures and a rachitic rosary when fed a VC-deficient diet, and die within $135 \mathrm{~d}^{(20)}$. Thus, SMP30KO mice are thought to be a more useful animal model for investigating the physiological functions of VC than widely used VC-deficient animals such as osteogenic disorder Shionogi (ODS) rats or guinea pigs.

In the present study, to investigate the effects of long-term high-dose VC intake on age-related changes in immune status, we estimated the daily dietary $\mathrm{VC}$ requirement of SMP30KO mice and fed these mice normal- or high-VC diets for 1 year, after which we measured the weights of immune organs and the numbers of immune cells in the peripheral blood, spleen and thymus.

\section{Materials and methods}

\section{Animals}

SMP30KO mice were generated from C57BL/6 mice by gene targeting, as described previously ${ }^{(19)}$. Specific pathogen-free male C57BL/6 (wild-type; WT) mice were purchased from Charles River Japan and were allowed to acclimatise for $7 \mathrm{~d}$ before the experiments. Throughout the experiments, mice were housed individually and maintained under specific pathogen-free conditions at our laboratory in a controlled environment (room temperature $23 \pm 1^{\circ} \mathrm{C}$, relative humidity $55 \pm 5 \%$ and photoperiod $12 \mathrm{~h}$ light $-12 \mathrm{~h}$ dark cycle). All experiments were performed with 6- to 7-week-old male SMP30KO mice and 7-week-old male WT mice in accordance with the guidelines of the Animal Care and Use Committee of the House Wellness Foods Corporation.

\section{Experimental design}

In a preliminary study, SMP30KO mice were fed a purified diet containing $0.02 \% \mathrm{VC}(20 \mathrm{mg} / \mathrm{kg}$ per d) for 5 months. Then, the plasma ascorbic acid concentration of SMP30KO mice was compared with that of age-matched WT mice to investigate whether our estimated RDA of VC was appropriate. The RDA was estimated by scaling the human dose down to an equivalent dose normalised to the body surface area. In the subsequent main study, SMP30KO mice were randomly allocated to two groups and fed a purified diet (Oriental Yeast Company) containing $0.02 \% \mathrm{VC}(n 10)$ or $0.2 \% \mathrm{VC}(n 11)$ for 1 year. The composition of the diet was based on the American Institute of Nutrition (AIN)-93M diet ${ }^{(21)}$, as detailed in Table 1. The sample size was determined from the results of a previous study on the effect of melatonin on thymic atrophy ${ }^{(22)}$. An estimated sample size of sixteen mice was based on an expected thymus weight of 26 (SD 4) $\mathrm{g}$ in aged C57BL/ 6 mice, a targeted $25 \%$ restoration of thymus weight, a statistical power of $80 \%$ and a type I error of $5 \%$. We initially allocated ten to eleven mice to each group to allow for an estimated $20 \%$ dropout rate over the study period. WT $\mathrm{C} 57 \mathrm{BL} / 6$ mice (WT group, $n$ 5) were fed a commercial diet (CE-2; CLEA Japan, Inc.) for 1 year and used as aged control mice. Mice were given the aforementioned diets and drinking-
Table 1. Composition of the basal $\operatorname{diet}^{\star} \dagger$

\begin{tabular}{lcc}
\hline Ingredients & $\begin{array}{r}0.02 \% \text { VC } \\
\text { (g/kg diet) }\end{array}$ & $\begin{array}{r}0.2 \% \text { VC } \\
\text { (g/kg diet) }\end{array}$ \\
\hline Maize starch & 465.5 & 463.7 \\
$\alpha$-Maize starch & 155.0 & 155.0 \\
Casein & 140.0 & 140.0 \\
Sucrose & $100 \cdot 0$ & $100 \cdot 0$ \\
Cellulose powder & 50.0 & 50.0 \\
Soyabean oil & 40.0 & 40.0 \\
Mineral mix (AIN-93M-MX) & 35.0 & 35.0 \\
Vitamin mix (AIN-93-VX) & 10.0 & 10.0 \\
Choline bitartrate & 2.5 & 2.5 \\
L-Cystine & 1.8 & 1.8 \\
tert-Butylhydroquinone (mg) & 8.0 & 8.0 \\
Ascorbic acid & 0.2 & 2.0 \\
\hline
\end{tabular}

VC, vitamin C; AIN, American Institute of Nutrition.

* The basal diet was based on the AIN-93M diet, which was supplemented with either $0.2 \%$ or $2.0 \%$ ascorbic acid.

† Mice in the wild-type group were fed a powdered CE-2 diet, which is adequate for normal growth. The CE-2 diet contains $89 \mathrm{~g}$ moisture, $249 \mathrm{~g}$ crude protein, $46 \mathrm{~g}$ crude fat, $41 \mathrm{~g}$ crude fibre, $66 \mathrm{~g}$ crude ash and $510 \mathrm{~g} \mathrm{~N}$-free extract per kg diet, with an energy content of $14.4 \mathrm{MJ} / \mathrm{kg}$

water without VC ad libitum throughout the study. After receiving the respective diets for 1 year, the body weight, organ weights and plasma ascorbic acid levels were measured, and peripheral blood leucocytes, splenocytes and thymocytes were prepared for further analyses. Mice were anaesthetised with diethyl ether, and blood samples were taken from the inferior vena cava before mice were killed by exsanguination.

\section{Measurement of plasma ascorbic acid levels}

The plasma level of ascorbic acid was measured by HPLC with electrochemical detection ${ }^{(23,24)}$. The plasma sample was vigorously mixed with an equal volume of $10 \%(\mathrm{w} / \mathrm{v})$ metaphosphoric acid containing $0 \cdot 2 \mathrm{~mm}-\mathrm{EDTA}-2 \mathrm{Na}$, and was then centrifuged at $8000 \mathrm{~g}$ for $10 \mathrm{~min}$ at $4^{\circ} \mathrm{C}$. The supernatant was collected and stored at $-80^{\circ} \mathrm{C}$ for only 1 week. Before HPLC analysis, the supernatant $(10 \mu \mathrm{l})$ was vigorously mixed with $40 \mu \mathrm{l}$ of $10 \%(\mathrm{w} / \mathrm{v}) \mathrm{TCA}$, and was then centrifuged at $5200 \mathrm{~g}$ for $10 \mathrm{~s}$ at room temperature. The supernatant $(10 \mu \mathrm{l})$ thus obtained was diluted with $40 \mu \mathrm{l}$ of the mobile phase and was then injected into a semi-micro HPLC system (Nanospace SI-2; Shiseido). Chromatographic separation was carried out on a Capcell Pak $\mathrm{C}_{18} \mathrm{MG}(3.0 \times 75 \mathrm{~mm}, 3 \mu \mathrm{m}$; Shiseido $)$ using an isocratic mobile phase $(0 \cdot 1 \mathrm{M}$-potassium phosphate buffer, $\mathrm{pH} 2 \cdot 0$ ). The flow rate was $400 \mu \mathrm{l} / \mathrm{min}$, the injection volume was $5 \mu \mathrm{l}$, and the column oven temperature was $40^{\circ} \mathrm{C}$. The electrochemical detector (Model 3016; Shiseido) was operated in the amperometric mode at an oxidation potential of $+700 \mathrm{mV}$.

\section{Preparation of leucocytes, splenocytes and thymocytes}

In one set of experiments, blood samples were incubated with cold lysis solution (150 mm-NH $4 \mathrm{Cl}, 10 \mathrm{~mm}-\mathrm{NaHCO}_{3}$ and $1.27 \mathrm{~mm}$-EDTA) for $5 \mathrm{~min}$ at room temperature. After centrifugation at $250 \mathrm{~g}$ for $5 \mathrm{~min}$ at $4^{\circ} \mathrm{C}$, the lysed erythrocytes were removed. The pellet of leucocytes was washed with 
PBS containing $2 \%$ fetal bovine serum (FBS) and resuspended in PBS containing $2 \%$ FBS. The spleen or thymus gland was initially minced with scissors and then mashed with the plunger of a syringe, after which the cell suspension was centrifuged at $250 \mathrm{~g}$ for $5 \mathrm{~min}$ at $4^{\circ} \mathrm{C}$. For thymus samples, after removing the supernatant, the pellet of thymocytes was washed and resuspended in PBS containing 2\% FBS. For spleen samples, after removing the supernatant, erythrocytes were lysed by incubation for $5 \mathrm{~min}$ at $4^{\circ} \mathrm{C}$ in lysis solution (17 $\mathrm{mm}_{-} \mathrm{NH}_{4} \mathrm{Cl}$ and $140 \mathrm{~mm}$-Tris-HCl, $\mathrm{pH}$ 8.0). Then, an excess of Hank's solution containing 10\% FBS was added and the suspension was centrifuged at $250 \boldsymbol{g}$ for $5 \mathrm{~min}$ at $4^{\circ} \mathrm{C}$. Subsequently, the pellet of splenocytes was washed and suspended in PBS containing 2\% FBS. Single-cell suspensions of leucocytes, splenocytes and thymocytes were obtained by passing each suspension through a $70 \mu \mathrm{m}$ nylon cell strainer (Nippon Becton-Dickinson Company Limited), and were used for cell counting.

\section{Cell counting}

Erythrocytes, total splenocytes and total thymocytes were counted with an automated cell counter (CDA-500; Sysmex). The absolute count of each population of leucocytes was analysed by flow cytometry (EPICS XL ADC) using EXPO 32 ADC software (Beckman Coulter, Inc.). In brief, the number of leucocytes was measured using Flow-Count ${ }^{\mathrm{TM}}$ (Beckman Coulter, Inc.), and the percentages of lymphocytes, granulocytes and monocytes in the gated population of leucocytes were determined. Then, the absolute count of each cell subpopulation was calculated by multiplying the total number of leucocytes by the percentage of each cell type.

\section{Antibodies}

Antibodies used in the present study were as follows: anticluster of differentiation (CD)3-fluorescein isothiocyanate (FITC) (clone 145-2C11; Santa Cruz Biotechnology, Inc.); antiCD4-phycoerythrin (PE) (clone RM4-5; eBioscience, Inc.); anti-CD8-peridinin chlorophyll protein complex (PerCP) (clone 53-6.7; Biolegend); anti-CD4-FITC (clone RM4-5; BD Pharmingen); anti-CD8-FITC (clone 53-6.7; Beckman Coulter, Inc.); anti-CD44-PE (clone KM201; Beckman Coulter, Inc.);
anti-CD45RB-PerCP/cyanine5.5 (clone C363-16A; Biolegend); anti-CD16/CD32 (clone 93; Biolegend).

\section{Flow cytometry}

Cells were pre-incubated with anti-CD16/CD32 antibodies to block Fc receptors and were then stained with each monoclonal antibody, according to the manufacturer's instructions. After staining, the cells were analysed on a flow cytometer. Thymocytes were stained with anti-CD4-PE and antiCD8-PerCP antibodies. Double-negative or double-positive thymocytes were defined as $\mathrm{CD} 4^{-} \mathrm{CD} 8^{-}$or $\mathrm{CD} 4^{+} \mathrm{CD} 8^{+}$thymocytes, respectively, while $\mathrm{CD} 4$ or $\mathrm{CD} 8$ single-positive (SP) thymocytes were defined as $\mathrm{CD} 4{ }^{+} \mathrm{CD} 8^{-}$or $\mathrm{CD} 4^{-} \mathrm{CD} 8^{+}$thymocytes, respectively. Leucocytes or splenocytes were stained with anti-CD3-FITC antibodies and with anti-CD4-PE or anti-CD8PerCP antibodies. In some experiments, these cells were also stained with anti-CD4-FITC or anti-CD8-FITC antibodies, followed by anti-CD44-PE and anti-CD45RB-PerCP/cyanine 5.5 antibodies. Among the SP T cells, CD $44^{\text {low }} \mathrm{CD} 45 \mathrm{RB}^{\text {high }}$ cells were defined as naive $\mathrm{T}$ cells, and $\mathrm{CD} 44^{\mathrm{high}} \mathrm{CD} 45 \mathrm{RB}{ }^{\text {low }}$ cells were defined as memory $\mathrm{T}$ cells. The absolute count of each cell subpopulation was calculated by multiplying the total number of thymocytes, splenocytes or lymphocytes by the percentage of each subpopulation.

\section{Statistical analysis}

Differences between the $0.02 \% \mathrm{VC}$ group and the $0.2 \% \mathrm{VC}$ group were assessed by unpaired Student's $t$ test using Statcel 2 software (OMS Publishing). Data are presented as means and standard deviations. A $P$ value $<0.05$ was considered as statistically significant.

\section{Results}

\section{Estimating the dietary vitamin $\mathrm{C}$ requirement of senescence marker protein-30 knockout mice}

Because the RDA for VC is $100 \mathrm{mg} / \mathrm{d}$ in Japan ${ }^{(6)}$, we estimated that the daily dietary $\mathrm{VC}$ requirement of SMP30KO mice was $20 \mathrm{mg} / \mathrm{kg}$ per $\mathrm{d}$ based on normalisation using the body surface area. To evaluate whether this estimate was appropriate, SMP30KO mice were fed a purified diet containing $0.02 \%$

Table 2. Effects of high dietary intake of vitamin C (VC) on body weight, thymus and spleen weights, and plasma ascorbic acid concentration in senescence marker protein-30 knockout mice (Mean values and standard deviations)

\begin{tabular}{|c|c|c|c|c|c|c|}
\hline & \multicolumn{2}{|c|}{$\begin{array}{c}0.02 \% \text { VC } \\
\text { group }(n 10)\end{array}$} & \multicolumn{2}{|c|}{$\begin{array}{c}0.2 \% \text { VC group } \\
(n 11)\end{array}$} & \multicolumn{2}{|c|}{ WT† } \\
\hline & Mean & SD & Mean & SD & Mean & SD \\
\hline Body weight $(\mathrm{g})$ & $43 \cdot 0$ & $5 \cdot 6$ & $45 \cdot 2$ & $5 \cdot 1$ & $46 \cdot 4$ & $8 \cdot 7$ \\
\hline Spleen weight (mg) & $106 \cdot 3$ & $20 \cdot 9$ & $118 \cdot 1$ & $14 \cdot 3$ & $78 \cdot 3$ & $8 \cdot 1$ \\
\hline Thymus weight (mg) & $13 \cdot 8$ & $3 \cdot 0$ & $28 \cdot 3^{\star \star}$ & 8.6 & $16 \cdot 1$ & $6 \cdot 6$ \\
\hline Plasma ascorbic acid concentration (mg/l) & $6 \cdot 2$ & $1 \cdot 2$ & $13 \cdot 7^{\star *}$ & $1 \cdot 7$ & $7 \cdot 1$ & $1 \cdot 1$ \\
\hline
\end{tabular}

WT, wild type.

Mean value was significantly different from that of the $0.02 \%$ VC group: ${ }^{\star \star} P<0.01$ (unpaired Student's $t$ test).

†Data obtained from age-matched WT mice are shown as reference $(n 5)$. 
Table 3. Effects of high dietary vitamin C (VC) intake on the number of peripheral blood cells, splenocytes and thymocytes in senescence marker protein-30 knockout mice (Mean values and standard deviations)

\begin{tabular}{|c|c|c|c|c|c|c|}
\hline & \multicolumn{2}{|c|}{$\begin{array}{c}0.02 \% \text { VC } \\
\text { group }(n 10)\end{array}$} & \multicolumn{2}{|c|}{$\begin{array}{c}0.2 \% \text { VC } \\
\text { group }(n 11)\end{array}$} & \multicolumn{2}{|c|}{ WT† } \\
\hline & Mean & SD & Mean & SD & Mean & SD \\
\hline Erythrocytes $\left(\times 10^{9} / \mathrm{ml}\right)$ & 8.03 & 1.04 & 8.65 & $1 \cdot 18$ & 8.57 & 0.90 \\
\hline Leucocytes $\left(\times 10^{6} / \mathrm{ml}\right)$ & $2 \cdot 33$ & 1.08 & $3 \cdot 84^{\star}$ & 1.66 & 1.88 & 0.61 \\
\hline Lymphocytes $\left(\times 10^{6} / \mathrm{ml}\right)$ & 1.80 & 0.90 & $3 \cdot 00^{\star}$ & 1.30 & 1.40 & 0.50 \\
\hline Granulocytes $\left(\times 10^{5} / \mathrm{ml}\right)$ & $2 \cdot 30$ & 1.33 & $4 \cdot 24^{\star \star}$ & 1.70 & 2.95 & 0.57 \\
\hline Monocytes $\left(\times 10^{5} / \mathrm{ml}\right)$ & 0.71 & 0.34 & $1 \cdot 21^{*}$ & 0.59 & 0.53 & 0.17 \\
\hline Splenocytes $\left(\times 10^{7}\right)$ & $13 \cdot 4$ & 1.9 & $16 \cdot 8^{\star \star}$ & 1.8 & 11.2 & $2 \cdot 3$ \\
\hline Thymocytes $\left(\times 10^{7}\right)$ & 2.09 & 0.75 & $3 \cdot 80^{\star}$ & 1.86 & 1.91 & 0.82 \\
\hline
\end{tabular}

WT, wild type.

Mean value was significantly different from that of the $0.02 \%$ VC group: ${ }^{\star} P<0.05,{ }^{* \star} P<0.01$ (unpaired Student's $t$ test).

†Data obtained from age-matched WT mice are shown as reference $(n 5)$

VC $(20 \mathrm{mg} / \mathrm{kg}$ per $\mathrm{d})$ for 5 months and the plasma ascorbic acid level of SMP30KO mice was compared with that of age-matched $\mathrm{C} 57 \mathrm{BL} / 6$ (WT) mice. The result revealed that the plasma ascorbic acid concentration of SMP30KO mice was almost the same as that of age-matched WT mice (6.6 (SD 1.7 ) and $6.8(\mathrm{SD} 0.8) \mathrm{mg} / 1, n 7$ and $n 5$, respectively) after 5 months on a diet containing $0.02 \% \mathrm{VC}(20 \mathrm{mg} / \mathrm{kg}$ per d). This demonstrated that the daily dietary $\mathrm{VC}$ requirement of SMP30KO mice was $20 \mathrm{mg} / \mathrm{kg}$ per $\mathrm{d}$.

\section{Effects of high vitamin C intake on body weight, organ weights and plasma ascorbic acid level in senescence marker protein-30 knockout mice}

To examine the influence of long-term high-dose VC intake on age-related changes in body weight, spleen and thymus weights, and plasma ascorbic acid level, twenty-one SMP30KO mice (mean body weight 21.4 (SD 0.4 ) g) were randomly divided into two groups and were fed a diet containing the recommended VC level $(0.02 \%, n 10)$ or a 10 -fold higher level of $\mathrm{VC}(0 \cdot 2 \%, n 11)$ for 1 year. No serious adverse events were observed in both experimental groups throughout the study. Body weight and spleen weight showed no significant differences between the two groups, whereas thymus weight was significantly higher in the $0.2 \% \mathrm{VC}$ group than in the $0.02 \%$ VC group after 1 year on the experimental diets. The plasma ascorbic acid level was also significantly higher in the $0 \cdot 2 \% \mathrm{VC}$ group than in the $0.02 \%$ VC group, which had a similar level to that of the age-matched WT group (Table 2).

\section{Effects of high vitamin C intake on peripheral blood cells, splenocytes and thymocytes}

To investigate the effect of high VC intake on age-related changes in immune cells, we measured the total number and the populations of leucocytes, splenocytes and thymocytes after 1 year on the respective experimental diets. As shown in Table 3, the total number of leucocytes, lymphocytes, granulocytes and monocytes in the peripheral blood was significantly higher in the $0.2 \% \mathrm{VC}$ group than in the
$0.02 \%$ VC group. The total number of splenocytes and thymocytes was also markedly higher in the $0.2 \% \mathrm{VC}$ group than in the $0.02 \%$ VC group. Immune cell numbers in the $0.02 \% \mathrm{VC}$ group were approximately the same as those in the WT group (Table 3 )

\section{Effects of high vitamin C intake on the subpopulations of leucocytes, splenocytes and thymocytes}

It is well known that thymic involution occurs with ageing, leading to a decrease in the number of naive $\mathrm{T}$ cells in the peripheral blood $^{(1,25,26)}$. Therefore, we assessed T-cell populations after 1 year on the respective experimental diets. Among peripheral blood lymphocytes, the number of ${ }_{\mathrm{CD}} 44^{\text {low }} \mathrm{CD} 45 \mathrm{RB}^{\text {high }}$ cells in both $\mathrm{CD}^{+}$and $\mathrm{CD}^{+}$T-cell populations (naive $\mathrm{CD}^{+}$and $\mathrm{CD}^{+} \mathrm{T}$ cells, respectively) was significantly higher in the $0.2 \% \mathrm{VC}$ group than in the $0.02 \%$ VC group, as were the number of $\mathrm{CD} 44^{\text {high }} \mathrm{CD} 45 \mathrm{RB}^{\text {low }}$ cells in both $\mathrm{CD}^{+}$and $\mathrm{CD}^{+}{ }^{+} \mathrm{T}$ cells (memory $\mathrm{CD}^{+}$and $\mathrm{CD}^{+}{ }^{+} \mathrm{T}$ cells, respectively) among splenocytes. Among thymocytes, although there was no significant difference in double-negative cells, the number of double-positive cells and $\mathrm{CD}^{+}$or $\mathrm{CD}^{+} \mathrm{SP}$ cells was significantly higher in the $0.2 \%$ VC group than in the $0.02 \%$ VC group (Table 4 ).

\section{Discussion}

In the present study, long-term high dietary intake of $\mathrm{VC}$ (at ten times the RDA) inhibited age-related thymic atrophy and maintained immune cells such as peripheral blood leucocytes, thymocytes and splenocytes in VC-deficient SMP30KO mice. In addition, the number of naive $\mathrm{T}$ cells in the peripheral blood and the memory T-cell populations of splenocytes was significantly higher in the $0.2 \% \mathrm{VC}$ group than in the $0.02 \%$ $\mathrm{VC}$ group. Among thymocytes, the number of double-positive cells and $\mathrm{CD}^{+}{ }^{+}$or $\mathrm{CD}^{+} \mathrm{SP}$ cell populations was also significantly larger in the $0.2 \% \mathrm{VC}$ group than in the $0.02 \% \mathrm{VC}$ group. These findings suggest that high dietary intake of $\mathrm{VC}$ over a long period contributes to sustaining immune cells, and could be effective in improving immune function in 
Table 4. Effects of high dietary vitamin $C$ (VC) intake on the T-cell subpopulations of peripheral blood lymphocytes, thymocytes and splenocytes in senescence marker protein-30 knockout mice

\begin{tabular}{|c|c|c|c|c|c|c|}
\hline & \multicolumn{2}{|c|}{$\begin{array}{c}0.02 \% \text { VC } \\
\text { group }(n 10)\end{array}$} & \multicolumn{2}{|c|}{$\begin{array}{c}0.2 \% \text { VC } \\
\text { group }(n 11)\end{array}$} & \multicolumn{2}{|c|}{ WT† } \\
\hline & Mean & SD & Mean & SD & Mean & SD \\
\hline \multicolumn{7}{|l|}{ T-cell subpopulations of peripheral blood lymphocytes } \\
\hline $\mathrm{CD}^{+} \mathrm{CD}^{+} \mathrm{T}$ cells $\left(\times 10^{4} / \mathrm{ml}\right)$ & 9.51 & 7.54 & $14 \cdot 3$ & 5.93 & 7.95 & 5.45 \\
\hline CD44 ${ }^{\text {low }}$ CD45RB ${ }^{\text {high }}$ cells (naive cells, $\times 10^{4} / \mathrm{ml}$ ) & $4 \cdot 27$ & $3 \cdot 27$ & $7 \cdot 19^{*}$ & 2.59 & 2.43 & 0.66 \\
\hline CD44 ${ }^{\text {high }}$ CD45RB ${ }^{\text {low }}$ cells (memory cells, $\times 10^{4} / \mathrm{ml}$ ) & 4.89 & 4.82 & $6 \cdot 38$ & $3 \cdot 19$ & $2 \cdot 71$ & 0.90 \\
\hline $\mathrm{CD}^{+} \mathrm{CD}^{+}{ }^{+}$cells $\left(\times 10^{4} / \mathrm{ml}\right)$ & $7 \cdot 10$ & $4 \cdot 17$ & $10 \cdot 6$ & 5.43 & 7.95 & 5.45 \\
\hline CD44 ${ }^{\text {low }}$ CD $45 R^{\text {high }}$ cells (naive cells, $\times 10^{4} / \mathrm{ml}$ ) & 1.03 & 0.58 & $1 \cdot 81^{*}$ & 0.85 & 1.23 & 0.85 \\
\hline CD44 ${ }^{\text {high }}$ CD 45 RB $^{\text {low }}$ cells (memory cells, $\times 10^{4} / \mathrm{ml}$ ) & $5 \cdot 68$ & 3.73 & $8 \cdot 20$ & 4.60 & $5 \cdot 64$ & 4.45 \\
\hline \multicolumn{7}{|l|}{ T-cell subpopulations of splenocytes } \\
\hline $\mathrm{CD}^{+}{ }^{+} \mathrm{CD} 4^{+} \mathrm{T}$ cells $\left(\times 10^{7}\right)$ & 2.04 & 0.67 & $3 \cdot 05^{\star}$ & 1.08 & $2 \cdot 10$ & 0.74 \\
\hline CD44 ${ }^{\text {low }}$ CD45RB ${ }^{\text {high }}$ cells (naive cells, $\times 10^{7}$ ) & 0.51 & 0.16 & 0.51 & 0.14 & 0.53 & 0.25 \\
\hline CD44 ${ }^{\text {high }}$ CD 45 RB ${ }^{\text {low }}$ cells (memory cells, $\times 10^{7}$ ) & 1.49 & 0.52 & $2 \cdot 48^{*}$ & 0.97 & 1.59 & 0.55 \\
\hline $\mathrm{CD}^{+} \mathrm{CD}^{+} \mathrm{T}$ cells $\left(\times 10^{7}\right)$ & $1 \cdot 12$ & 0.32 & 1.43 & 0.42 & 0.99 & 0.35 \\
\hline CD44 ${ }^{\text {low }} C D 45 R^{\text {high }}$ cells (naive cells, $\times 10^{7}$ ) & 0.18 & 0.12 & 0.13 & 0.05 & $0 \cdot 12$ & 0.07 \\
\hline $\mathrm{CD}_{44^{\text {high }}} \mathrm{CD}_{45 \mathrm{RB}^{\text {low }}}$ cells (memory cells, $\times 10^{7}$ ) & 0.91 & 0.21 & $1 \cdot 28^{*}$ & 0.39 & 0.84 & 0.33 \\
\hline \multicolumn{7}{|l|}{ T-cell subpopulations of thymocytes } \\
\hline CD4 ${ }^{-} \mathrm{CD}^{-}$cells $\left(\mathrm{DN}\right.$ cells, $\left.\times 10^{7}\right)$ & $0 \cdot 10$ & 0.03 & 0.23 & 0.22 & $0 \cdot 15$ & 0.07 \\
\hline $\mathrm{CD}^{+}{ }^{+} \mathrm{CD} 8^{+}$cells $\left(\mathrm{DP}\right.$ cells, $\times 10^{7}$ ) & 1.75 & 0.64 & $3 \cdot 13^{\star}$ & 1.38 & 1.47 & 1.05 \\
\hline $\mathrm{CD}^{+}{ }^{+} \mathrm{CD} 8^{-}$cells $\left(\mathrm{SP}\right.$ cells, $\left.\times 10^{7}\right)$ & 0.20 & 0.07 & $0.33^{*}$ & 0.17 & 0.16 & 0.08 \\
\hline $\mathrm{CD}^{-} \mathrm{CD}^{+}$cells $\left(\mathrm{SP}\right.$ cells, $\left.\times 10^{7^{\prime}}\right)$ & 0.06 & 0.02 & $0.12^{*}$ & 0.07 & 0.06 & 0.03 \\
\hline
\end{tabular}

WT, wild type; CD, cluster of differentiation; DN, double negative; DP, double positive; SP, single positive.

Mean value was significantly different from that of the $0.02 \%$ VC group: ${ }^{\star} P<0.05$ (unpaired Student's $t$ test).

† Data obtained from age-matched WT mice are shown as reference $(n 5)$.

elderly people by preventing a decline in the number of immune cells.

SMP30KO mice cannot synthesise VC due to genetic disruption of the Rgn gene that encodes gluconolactonase, so this is a useful animal model for investigating the actions of VC. The daily dietary VC requirement of SMP30KO mice was estimated to be $20 \mathrm{mg} / \mathrm{kg}$ per $\mathrm{d}$ based on normalisation using the body surface area, and mice were fed a diet containing this $\mathrm{VC}$ level $(20 \mathrm{mg} / \mathrm{kg}$ per d; $0.02 \%)$ or a high VC level $(200 \mathrm{mg} / \mathrm{kg}$ per $\mathrm{d} ; 0 \cdot 2 \%$ ). Plasma ascorbic acid concentration (Table 2) and the number of peripheral blood immune cells, splenocytes and thymocytes (Table 3) in SMP30KO mice fed a diet containing $0.02 \% \mathrm{VC}$ were similar to those in age-matched WT mice after 1 year on a conventional diet (CE-2). These observations suggested that SMP30KO mice from the $0.02 \%$ VC group were similar to age-matched WT mice.

Age-related thymic atrophy is characterised by a progressive decrease in the size of the thymus and structural changes ${ }^{(27)}$. Thymic atrophy has been demonstrated to be caused by a failure of the thymic microenvironment to support thymopoiesis and T-cell development ${ }^{(3)}$. The extracellular matrix is an important component of the thymic microenvironment, which interacts with thymocytes to drive their trafficking inside the thymus. Lannes-Vieira et al. ${ }^{(28)}$ studied the thymus in normal young mice and found that type I collagen is restricted to the interstitial spaces of the capsule and septae, whereas type IV collagen, fibronectin and laminin can be detected in the basement membrane, mostly in the inner cortex and outer medulla. Other researchers have reported that the size of both the cortex and medulla of the thymus decreases with age ${ }^{(29)}$. Because VC promotes the production of fibronectin, laminin and collagen by trabecular meshwork cells ${ }^{(30)}$, these components of the thymic extracellular matrix may be sustained in SMP30KO mice by long-term high dietary $\mathrm{VC}$ intake, and this may be one mechanism by which thymic atrophy was inhibited in the present study.

Thiobarbituric acid-reactive substances are a marker of oxidative stress that increase in the thymus with age, followed by the acceleration of thymic involution and the loss of thymocytes ${ }^{(31-33)}$. Melatonin is a strong antioxidant, and either long-term ( 8 months) or short-term ( 2 months) melatonin consumption prevents age-dependent thymic atrophy and attenuates apoptotic thymocyte death caused by free radicals in aged $\mathrm{BALB} / \mathrm{c}$ and $\mathrm{C} 57 \mathrm{BL} / 6$ mice ${ }^{(22,34)}$. It is possible that the high dose of $\mathrm{VC}$ used in the present study had a strong antioxidant effect, inhibiting both age-dependent involution of the thymus and the resulting loss of thymocytes. There is a significant age-associated increase in apoptosis that affects the double-negative cell population of thymocytes, partly due to the elevated expression of the cell death gene caspase- 3 in aged mice ${ }^{(35,36)}$. VC has been shown to inhibit thymocyte apoptosis by up-regulating the expression of the anti-apoptotic protein B-cell lymphoma- $2^{(37-39)}$. We found that the total number of thymocytes and the number of double-positive cells and $\mathrm{CD}^{+}$or $\mathrm{CD}^{+}$SP thymocyte subpopulations were markedly higher in the $0.2 \% \mathrm{VC}$ group than in the $0.02 \%$ VC group after 1 year of dietary treatment, possibly reflecting the inhibitory effect of high-dose dietary VC intake on the apoptosis of thymocytes through the induction of B-cell lymphoma-2. In contrast, recent studies have shown that the SMP30 protein has a suppressive effect on apoptosis induced by various factors ${ }^{(40)}$, although it is unclear how much of the SMP30 protein is involved in inhibiting age-related thymic involution and the apoptosis of thymocytes. Because the thymus weight and plasma VC level of SMP30KO mice fed the diet containing $0.02 \%$ VC were 
almost the same as those found in age-matched WT mice that had a sufficient amount of the SMP30 protein (Table 2), the inhibitory effect of SMP30 on thymic atrophy might be smaller than that of $\mathrm{VC}$.

We also demonstrated that the number of peripheral blood lymphocytes, particularly naive $\mathrm{CD}^{+}$and $\mathrm{CD}^{+} \mathrm{T}$ cells, that have the ability to fight new infections, was significantly higher in the $0.2 \% \mathrm{VC}$ group than in the $0.02 \% \mathrm{VC}$ group (Table 4). An age-related deterioration of thymic production is thought to be one of the major factors leading to a decline in the number of naive $\mathrm{T}$ cells in the peripheral blood $^{(1)}$. The long-term high dietary intake of $\mathrm{VC}$ may have ameliorated this decline of thymic cellular output, providing a stable supply of naive $T$ cells in aged mice. We do not know why memory $\mathrm{T}$ cells were sustained at a high level among splenocytes in the $0.2 \%$ VC group; however, this may have been related to the maintained thymic production of naive $\mathrm{T}$ cells.

The number of peripheral blood granulocytes or monocytes, which are recruited from the bone marrow to the periphery without passing through the thymus, was also higher in the $0.2 \% \mathrm{VC}$ group than in the $0.02 \% \mathrm{VC}$ group. Haematopoietic stem cells in the bone marrow generate multiple haematopoietic lineages through a series of intermediate progenitors. These progenitor cells include common lymphoid progenitors that can generate B cells, T cells or natural killer (NK) cells, and common myeloid progenitors that can generate erythrocytes, platelets, granulocytes or monocytes ${ }^{(41,42)}$. Mesenchymal stem cells are a population of pluripotent cells within the bone marrow microenvironment, which participate in the regulation of the self-renewal and differentiation of haematopoietic stem cells $^{(43)}$. Several studies have indicated that VC can induce proliferation and differentiation of bone marrow-derived mesenchymal stem cells in a dose-dependent manner ${ }^{(44)}$. Therefore, it seems that high dietary VC intake improves agerelated dysfunction of the bone marrow microenvironment, thereby permitting the maintenance of a wide variety of immune cells, not only $\mathrm{T}$ cells that are produced in the bone marrow and matured within the thymus, but also granulocytes and monocytes that are released directly into the peripheral blood from the bone marrow. It is well established that ageing affects acquired or innate immune functions as well as the number of immune cells ${ }^{(45)}$. To clarify the effect that VC has on various immune functions, further studies employing SMP30KO mice will be needed.

In conclusion, we demonstrated that high dietary intake of VC inhibited age-related thymic involution and maintained thymic output, resulting in stable peripheral immune cell counts in aged SMP30KO mice. The results from the present study suggest that long-term high dietary intake of VC may be effective in the maintenance of immune cells in elderly people.

\section{Acknowledgements}

The authors greatly appreciate Dr Norio Yamamoto for devising the HPLC method with electrochemical detection. The authors also thank Dr Koutarou Muroyama, Kengo Kawasaki,
Tatsuya Ohara, Youhei Higashi and Yuuske Tanaka for their technical assistance.

This research received no specific grant from any funding agency, commercial or not-for-profit sectors.

The author's contributions are as follows: R. U., Y. H. and S. M. designed the study; R. U. conducted the study; R. U. and Y. H. analysed the data; Y. Y. and A. I. participated in the interpretation of the results; R. U. wrote the manuscript; S. M. had primary responsibility for the final content of the manuscript. All authors read and approved the final manuscript.

The authors declare that they have no conflict of interest.

\section{References}

1. Gruver AL, Hudson LL \& Sempowski GD (2007) Immunosenescence of ageing. J Pathol 211, 144-156.

2. Haynes BF, Markert ML, Sempowski GD, et al. (2000) The role of the thymus in immune reconstitution in aging, bone marrow transplantation, and HIV-1 infection. Annu Rev Immunol 18, 529-560.

3. Linton PJ \& Dorshkind K (2004) Age-related changes in lymphocyte development and function. Nat Immunol $\mathbf{5}$, 133-139.

4. Rebouche CJ (1991) Ascorbic acid and carnitine biosynthesis. Am J Clin Nutr 54, 1147S-1152S.

5. Li Y \& Schellhorn HE (2007) New developments and novel therapeutic perspectives for vitamin C. J Nutr 137, 2171-2184.

6. Levine M, Wang Y, Padayatty SJ, et al. (2001) A new recommended dietary allowance of vitamin $\mathrm{C}$ for healthy young women. Proc Natl Acad Sci U S A 98, 9842-9846.

7. Huang HY, Appel LJ, Croft KD, et al. (2002) Effects of vitamin C and vitamin $\mathrm{E}$ on in vivo lipid peroxidation: results of a randomized controlled trial. Am J Clin Nutr 76, 549-555.

8. Nakhostin-Roohi B, Babaei P, Rahmani-Nia F, et al. (2008) Effect of vitamin $\mathrm{C}$ supplementation on lipid peroxidation, muscle damage and inflammation after 30-min exercise at $75 \% \mathrm{VO}_{2 \max }$. J Sports Med Phys Fitness 48, 217-224.

9. Panayiotidis M \& Collins AR (1997) Ex vivo assessment of lymphocyte antioxidant status using the comet assay. Free Radic Res 27, 533-537.

10. Shidfar F, Keshavarz A, Jallali M, et al. (2003) Comparison of the effects of simultaneous administration of vitamin $C$ and omega-3 fatty acids on lipoproteins, apo A-I, apo B, and malondialdehyde in hyperlipidemic patients. Int J Vitam Nutr Res 73, 163-170.

11. Wilkinson IB, Megson IL, MacCallum H, et al. (1999) Oral vitamin $C$ reduces arterial stiffness and platelet aggregation in humans. J Cardiovasc Pharmacol 34, 690-693.

12. Morel O, Jesel L, Hugel B, et al. (2003) Protective effects of vitamin $\mathrm{C}$ on endothelium damage and platelet activation during myocardial infarction in patients with sustained generation of circulating microparticles. J Thromb Haemost 1, $171-177$.

13. Van Straten M \& Josling P (2002) Preventing the common cold with a vitamin $C$ supplement: a double-blind, placebocontrolled survey. Adv Ther 19, 151-159.

14. Levine M, Dhariwal KR, Wang Y, et al. (1994) Ascorbic acid in neutrophils. In Natural Antioxidants in Health and Disease, pp. 469-488 [B Frei, editor]. San Diego, CA: Academic Press.

15. Jacob RA, Kelley DS, Pianalto FS, et al. (1991) Immunocompetence and oxidant defense during ascorbate depletion of healthy men. Am J Clin Nutr 54, 1302S-1309S. 
16. Panush RS, Delafuente JC, Katz P, et al. (1982) Modulation of certain immunologic responses by vitamin C. III. Potentiation of in vitro and in vivo lymphocyte responses. Int J Vitam Nutr Res Suppl 23, 35-47.

17. Fujita T, Uchida K \& Maruyama N (1992) Purification of senescence marker protein-30 (SMP30) and its androgenindependent decrease with age in the rat liver. Biochim Biophys Acta 1116, 122-128.

18. Maruyama N, Ishigami A \& Kondo Y (2010) Pathophysiological significance of senescence marker protein-30. Geriatr Gerontol Int 10, Suppl. 1, S88-S98.

19. Ishigami A, Fujita T, Handa S, et al. (2002) Senescence marker protein-30 knockout mouse liver is highly susceptible to tumor necrosis factor- $\alpha$ - and Fas-mediated apoptosis. Am J Pathol 161, 1273-1281.

20. Kondo Y, Inai Y, Sato Y, et al. (2006) Senescence marker protein 30 functions as gluconolactonase in L-ascorbic acid biosynthesis, and its knockout mice are prone to scurvy. Proc Natl Acad Sci U S A 103, 5723-5728.

21. Reeves PG, Nielsen FH \& Fahey GC Jr (1993) AIN-93 purified diets for laboratory rodents: final report of the American Institute of Nutrition ad boc writing committee on the reformulation of the AIN-76A rodent diet. J Nutr 123, 1939-1951.

22. Tian YM, Zhang GY \& Dai YR (2003) Melatonin rejuvenates degenerated thymus and redresses peripheral immune functions in aged mice. Immunol Lett 88, 101-104.

23. Umegaki K, Nishimuta M \& Esashi T (1999) A practical method for determination of vitamin $\mathrm{C}$ in plasma by highperformance liquid chromatography with an electrochemical detector. J Jpn Soc Nutr Food Sci 52, 107-111.

24. Margolis SA \& Davis TP (1988) Stabilization of ascorbic acid in human plasma, and its liquid-chromatographic measurement. Clin Chem 34, 2217-2223.

25. Elmore SA (2006) Enhanced histopathology of the spleen. Toxicol Pathol 34, 648-655.

26. den Braber I, Mugwagwa T, Vrisekoop N, et al. (2012) Maintenance of peripheral naive $\mathrm{T}$ cells is sustained by thymus output in mice but not humans. Immunity 36, 288-297.

27. Gui J, Mustachio LM, Su DM, et al. (2012) Thymus size and age-related thymic involution: early programming, sexual dimorphism, progenitors and stroma. Aging Dis 3, 280-290.

28. Lannes-Vieira J, Dardenne M \& Savino W (1991) Extracellular matrix components of the mouse thymus microenvironment: ontogenetic studies and modulation by glucocorticoid hormones. J Histochem Cytochem 39, 1539-1546.

29. Pesic V, Radojevic K, Kosec D, et al. (2007) Peripubertal orchidectomy transitorily affects age-associated thymic involution in rats. Braz J Med Biol Res 40, 1481-1493.

30. Zhou L, Higginbotham EJ \& Yue BY (1998) Effects of ascorbic acid on levels of fibronectin, laminin and collagen type 1 in bovine trabecular meshwork in organ culture Curr Eye Res 17, 211-217.

31. Kujoth GC, Hiona A, Pugh TD, et al. (2005) Mitochondrial DNA mutations, oxidative stress, and apoptosis in mammalian aging. Science 309, 481-484.

32. Migliaccio E, Giorgio M, Mele S, et al. (1999) The $\mathrm{p} 66^{\text {shc }}$ adaptor protein controls oxidative stress response and life span in mammals. Nature 402, 309-313.

33. Sverko V, Balog T, Sobocanec S, et al. (2002) Age-associated alteration of lipid peroxidation and superoxide dismutase activity in CBA and AKR mice. Exp Gerontol 37, 1031-1039.

34. Provinciali M, Di Stefano G, Bulian D, et al. (1996) Effect of melatonin and pineal grafting on thymocyte apoptosis in aging mice. Mech Ageing Dev 90, 1-19.

35. Andrew D \& Aspinall R (2001) IL-7 and not stem cell factor reverses both the increase in apoptosis and the decline in thymopoiesis seen in aged mice. J Immunol 166, $1524-1530$.

36. Kapasi AA \& Singhal PC (1999) Aging splenocyte and thymocyte apoptosis is associated with enhanced expression of p53, bax, and caspase-3. Mol Cell Biol Res Commun 1, $78-81$.

37. Pavlovic V, Pavlovic D, Kamenov B, et al. (2012) Protective role of vitamin $\mathrm{C}$ in diazepam-induced apoptosis in rat thymocytes. Bratisl Lek Listy 113, 350-353.

38. Pavlovic V, Pavlovic D, Kocic G, et al. (2009) Ascorbic acid modulates monosodium glutamate induced cytotoxicity in rat thymus. Bratisl Lek Listy 110, 205-209.

39. Maellaro E, Bello BD \& Comporti M (1996) Protection by ascorbate against apoptosis of thymocytes: implications of ascorbate-induced nonlethal oxidative stress and poly(ADP-ribosyl)ation. Exp Cell Res 226, 105-113.

40. Yamaguchi M (2013) The anti-apoptotic effect of regucalcin is mediated through multisignaling pathways. Apoptosis 18, $1145-1153$.

41. Akashi K, Traver D, Miyamoto T, et al. (2000) A clonogenic common myeloid progenitor that gives rise to all myeloid lineages. Nature 404, 193-197.

42. Kondo M, Weissman IL \& Akashi K (1997) Identification of clonogenic common lymphoid progenitors in mouse bone marrow. Cell 91, 661-672.

43. Larghero J, Vija L, Lecourt S, et al. (2009) Mesenchymal stem cells and immunomodulation: toward new immunosuppressive strategies for the treatment of autoimmune diseases? Rev Med Interne 30, 287-299.

44. Choi KM, Seo YK, Yoon HH, et al. (2008) Effect of ascorbic acid on bone marrow-derived mesenchymal stem cell proliferation and differentiation. J Biosci Bioeng 105, 586-594.

45. Srinivasan V, Maestroni GJ \& Cardinali DP (2005) Melatonin immune function and aging. Immun Ageing 2, 17. 